\title{
Study on Marketing Cost and Margins of Cluster bean in Bikaner District of Rajasthan
}

\author{
Mukesh Jyani1 ${ }^{*}$, Hemant Sharma ${ }^{2}$ and Meera $^{3}$ \\ ${ }^{1}$ Banaras Hindu University, Varanasi, Uttar Pradesh, India \\ ${ }^{2}$ Agro Economic Research Centre, Anand, Gujarat, India \\ ${ }^{3}$ Swami Keshwanand Rajasthan Agricultural University, Bikaner, Rajasthan, India \\ *Corresponding author: mukeshjyani36@gmail.com
}

\begin{abstract}
The present study was conducted to analyze the marketing cost and margins of cluster bean. The study was conducted in Bikaner district, Rajasthan. It has been observed from the study that the marketing cost incurred by the producer, wholesaler, miller and retailer is varied extensively over the channels. It is also evident that channel-II comprising of Producer-Wholesaler-Retailer- Consumer is more efficient than the other two channels. The study concluded that subsidized transportation facilities during harvesting along with establishment of sound market intelligence system may be helpful for the cluster bean farmers to fetch remunerative prices for their crop.
\end{abstract}

Keywords: Marketing Cost, Market Margin, Middlemen, Clusterbean

Cluster bean has also witnessed price volatility and uncertainty owing to limited area of production, increasing demand, speculation, lack of reliable market information system etc. The analysis of historical data and of relative share of different states in the total production and area shows that Rajasthan is the leading producer but suffers from high fluctuation in production. The significantly higher prices of cluster bean in recent time have helped expand the crop to non-traditional regions and seasons. The demand of processed cluster bean in world market is expected to increase with the expansion of shale oil gas tracking to new countries like China and Russia and scaling up in prominent existing countries like USA along with other uses in food and textile industries owing to increased food safety and health concerns. The expansion of uses of cluster bean to new areas like extraction of natural and shale gas has transformed cluster bean in recent years into an important export crop. India is the largest producer of guar gum and its derivatives. Guar gum is largely an export oriented commodity with about $75-80$ per cent of total output being exported from the country. India was the leading exporter of mucilage's and a thickener in the world with a Share of USA in total export of Guar gum from India during 201213 was reported to be nearly 60 per cent (NIAM, 2014). In recent years the crop has acquired great significance due to its use in the oil drilling industry for hydraulic fracturing of oil shale, mainly by the United States for its concern for the environment and water contamination. United States is the largest producer of shale gas with a huge reservoir of around 665 trillion cubic feet (Energy Information Administration estimates). In recent years, the production of shale gas has increased many folds in the United States. The use of fast hydrated gum as a key ingredient in the process of frocking has helped in consolidating the demand of crop in the international market (Mudgil et al. 2014). Increasing demand of cluster bean on account of growth in shale gas industry along with other factors has made cluster bean a golden crop. The increased demand has resulted in a strong escalation of the prices of cluster bean beans and products. Nevertheless, the 
prices of cluster bean has shown uncertainty and volatility as the crop is mainly cultivated under rainfed conditions and its production is confined largely to limited geographical area. In addition to increased prices, the multi utility nature of the crop has generated a lot of interest for the crop among different stakeholder. The trajectory of the growth of cluster bean industry has been upward.

Processors after processing cluster bean seed into split either it export directly or through the exporters. Processors also sell cluster bean split to the local gum processors. Similarly, gum processors source cluster bean either from village traders, farmers through commission agents, stockist/ traders or procure split from split manufacturers. After processing of cluster bean split into different industry specific guar gum products, the final product is exported and/or made available to the domestic market. The assessment of current stocks and carryover stock in this situation is quite difficult and hence, leads to speculation. Although, market forces determine the price in long run but the cluster bean industry has witnessed high price fluctuations in the recent years (NIAM, 2015). The surge in demand in the international market and the consequent strong surge in prices has created an interest for the cluster bean crop amongst all the stakeholders involved in the marketing and distribution. Thus, keeping in the above view about guar, the present study was undertaken to study marketing of cluster bean (Cyamposis tetragonoloba) in Bikaner district of Rajasthan.

\section{Database and Methodology}

Bikaner district of North-Western Rajasthan is one of major producing districts of cluster bean and therefore, the Bikaner district was selected purposively. On the basis of highest area under cluster bean, Lunkaransar tehsil of Bikaner district was selected for the study. Agriculture Mandi of Lunkaransar was selected on the basis of highest arrivals of cluster bean in the market. Investigation regarding different marketing channels was done by selecting a random sample of different intermediaries like farmer producer, wholesaler, commission agent and retailers. Ten intermediaries were selected from each group. The primary data required for the study were collected by personal interview of the sample farmers, wholesalers, commission agents and retailers. The information were collected from farmers, village traders, wholesalers, retailers and market traders regarding disposal pattern to identify the existing marketing channels prevailing in the cluster bean trade. Cost of marketing, marketing efficiency etc. is calculated based on standard procedures which are discussed below.

Marketing Cost $(\mathrm{MC})=\mathrm{CP}+\mathrm{CM}$

Where,

$\mathrm{CP}=$ Cost incurred by producer in marketing of produce

$\mathrm{CM}=$ Cost incurred by the middleman

Acharya's measure of marketing efficiency has been employed in order to study the marketing efficiency.

Marketing Efficiency $(\mathrm{ME})=\frac{\mathrm{FP}}{\mathrm{MC}+\mathrm{MM}}$

Where,

$\mathrm{FP}=$ net price receive by farmer $[₹ / \mathrm{qtl}]$

$\mathrm{MC}=$ total marketing cost $(₹ / \mathrm{qtl})$

$\mathrm{MM}=$ total marketing margins of intermediaries (₹/qtl)

Major marketing channels of cluster bean were identified in the study area which is described below:

Channel-I: Producer $\rightarrow$ Wholesaler $\rightarrow$ Miller $\rightarrow$ Retailer $\rightarrow$ Consumer

Channel-II: Producer $\rightarrow$ Wholesaler $\rightarrow$ Retailer $\rightarrow$ Consumer

Channel-III: Producer $\rightarrow$ Commission agent Wholesaler $\rightarrow$ Retailer $\rightarrow$ Consumer

\section{RESULTS AND DISCUSSION}

The marketing costs in channel-I indicates in table 1 that the cost incurred by producer was $₹ 55$ per quintal of cluster bean which was 0.86 per cent of consumer rupee. Cost incurred by wholesaler was ₹ 81.70 per quintal of cluster bean which was 1.28 per cent of consumer rupee. Cost incurred by miller was ₹ 335.83 per quintal of cluster bean which was 5.30 per cent of consumer rupee. Processing of cluster bean in primary stage by miller was done removing of the cluster bean husk and grain (endosperm) and miller sales the husk to the retailer 
for the feeding animals and grain (endosperm) is sold to the manufactures for further processing and manufacturing of products such as cluster bean gum. Cost incurred by retailer was ₹ 33.00 per quintal of cluster bean which was 0.52 per cent of consumer rupee. The farmer share in the consumer rupee was 79.64 per cent in channel-I.

Table 2 indicates that the cost incurred by the producer was ₹ 55 per quintal of cluster bean which was 0.99 per cent of consumer rupee. Cost incurred by the wholesaler was ₹ 133.35 per quintal of cluster bean which was 2.41 per cent of consumer rupee. Cost incurred by retailer was ₹ 33 per quintal of cluster bean which was 0.59 per cent of consumer rupee. The farmer share was 91.71 per cent in consumer rupee in channel 11.

Table 1: Marketing cost and price spread of cluster bean in Channel I

\begin{tabular}{|c|c|c|}
\hline Particulars & ₹/qtl & $\begin{array}{c}\% \text { share in } \\
\text { consumer rupee }\end{array}$ \\
\hline $\begin{array}{c}\text { Net price received by } \\
\text { producer }\end{array}$ & 5045 & 79.64 \\
\hline \multicolumn{3}{|l|}{ Cost incurred by producer } \\
\hline Loading cost & 3 & 0.04 \\
\hline Unloading cost & 2 & 0.03 \\
\hline Transportation & 20 & 0.31 \\
\hline Gunny bags & 30 & 0.47 \\
\hline Total cost & 55 & 0.86 \\
\hline $\begin{array}{c}\text { Sale price of producer/ } \\
\text { purchase price of wholesaler }\end{array}$ & 5100 & 80.51 \\
\hline Mandi tax@1.6\% & 81.60 & 1.28 \\
\hline Weighing@0.10/qtl & 0.10 & 0.001 \\
\hline Total cost & 81.70 & 1.28 \\
\hline Net margin of wholesaler & 102 & 1.61 \\
\hline $\begin{array}{l}\text { Sale price of wholesaler/ } \\
\text { purchase price of miller }\end{array}$ & 5283.7 & 83.41 \\
\hline Sale tax@1\% & 52.83 & 0.83 \\
\hline Loading & 3 & 0.04 \\
\hline Unloading & 2 & 0.03 \\
\hline Transportation & 20 & 0.31 \\
\hline Storage cost & 8 & 0.12 \\
\hline Processing cost & 250 & 3.94 \\
\hline Total cost & 335.83 & 5.30 \\
\hline Net margin of miller & 528.37 & 8.34 \\
\hline $\begin{array}{l}\text { Sale price of miller/purchase } \\
\text { price of retailer and } \\
\text { manufacturer of cluster bean } \\
\text { product }\end{array}$ & 6147.90 & 97.05 \\
\hline Loading & 3 & 0.047 \\
\hline
\end{tabular}

\begin{tabular}{ccc} 
Unloading & 2 & 0.03 \\
Transportation & 20 & 0.31 \\
Storage cost & 8 & 0.12 \\
Total cost & 33 & 0.52 \\
Net margin of retailer & 153.69 & 2.42 \\
Retailer's selling price/ & 6334.59 & 100 \\
consumer purchase price & & \\
\hline
\end{tabular}

The marketing costs in channel-III (Table 2) indicate that the total cost incurred by producer was ₹ 55 per quintal which was 0.96 per cent of the consumer rupee. Cost incurred by commission agent was ₹ 82.5 per quintal which was 1.44 per cent of the consumer rupee. Cost incurred by wholesaler was $₹ 79.18$ per quintal which was 1.38 per cent of the consumer rupee. Cost incurred by retailer was ₹ 38 per quintal of cluster bean which was 0.66 per cent of the consumer rupee. The farmer share in consumer rupee was 89.43 per cent in consumer rupee. These results are in accordance with the findings of Thakare et al. (2011) who also observed the similar results on production and marketing of cowpea in Amravati district of Maharashtra.

Table 2: Marketing cost of cluster bean in Channel-II and III

\begin{tabular}{|c|c|c|}
\hline Particulars & ₹/qtl & $\begin{array}{c}\% \text { share in } \\
\text { consumer rupee }\end{array}$ \\
\hline \multicolumn{3}{|c|}{ Channel-II } \\
\hline $\begin{array}{c}\text { Net price received by } \\
\text { producer }\end{array}$ & 5070 & 91.71 \\
\hline \multicolumn{3}{|l|}{ Cost incurred by producer } \\
\hline Loading cost & 3 & 0.05 \\
\hline Unloading cost & 2 & 0.03 \\
\hline Transportation & 20 & 0.36 \\
\hline Gunny bags & 30 & 0.54 \\
\hline Total cost & 55 & 0.99 \\
\hline $\begin{array}{c}\text { Producer Sale price / } \\
\text { wholesaler purchase price }\end{array}$ & 5125 & 92.71 \\
\hline Mandi tax@1.6\% & 82 & 1.48 \\
\hline Sale tax @ 1\% & 51.25 & 0.92 \\
\hline Weighing & 0.1 & 0.001 \\
\hline Total cost & 133.35 & 2.41 \\
\hline Net margin of wholesaler & 102.5 & 1.85 \\
\hline $\begin{array}{l}\text { Sale price of wholesaler/ } \\
\text { purchase price of Retailer }\end{array}$ & 5360.85 & 96.97 \\
\hline Loading & 3 & 0.05 \\
\hline Unloading & 2 & 0.03 \\
\hline Transportation & 20 & 0.36 \\
\hline Storage cost & 8 & 0.14 \\
\hline
\end{tabular}




\begin{tabular}{|c|c|c|}
\hline Total cost & 33 & 0.59 \\
\hline Net margin of Retailer & 134.021 & 2.42 \\
\hline $\begin{array}{l}\text { Retailer sale price / } \\
\text { Consumer's purchase price }\end{array}$ & 5527.87 & 100.00 \\
\hline \multicolumn{3}{|c|}{ Channel-III } \\
\hline $\begin{array}{c}\text { Net price received by } \\
\text { producer }\end{array}$ & 5095 & 89.43 \\
\hline \multicolumn{3}{|l|}{ Cost incurred by producer } \\
\hline Loading cost & 3 & 0.05 \\
\hline Unloading cost & 2 & 0.03 \\
\hline Transportation & 20 & 0.35 \\
\hline Gunny bags & 30 & 0.52 \\
\hline Total cost & 55 & 0.96 \\
\hline $\begin{array}{c}\text { Producer Sale price / } \\
\text { commission agent's purchase } \\
\text { price }\end{array}$ & 5150 & 90.39 \\
\hline Mandi tax@1.6\% & 82.4 & 1.44 \\
\hline Weighing & .10 & 0.001 \\
\hline Total cost & 82.50 & 1.44 \\
\hline Net margin of CA & 103 & 1.80 \\
\hline $\begin{array}{l}\text { Commission agent's Sale price } \\
\text { /Wholesaler purchase price }\end{array}$ & 5335.5 & 93.64 \\
\hline Loading & 3 & 0.05 \\
\hline Unloading & 2 & 0.03 \\
\hline Transportation & 20 & 0.35 \\
\hline Sale tax@1\% & 54.18 & 0.95 \\
\hline Total cost & 79.18 & 1.38 \\
\hline Net margin of wholesaler & 106.71 & 1.87 \\
\hline $\begin{array}{l}\text { Wholesaler sale price / } \\
\text { Retailer purchase price }\end{array}$ & 5521.39 & 96.91 \\
\hline Loading & 3 & 0.05 \\
\hline Unloading & 2 & 0.03 \\
\hline Transportation & 25 & 0.43 \\
\hline Storage cost & 8 & 0.14 \\
\hline Total cost & 38 & 0.66 \\
\hline Net margin of Retailer & 138.03 & 2.42 \\
\hline $\begin{array}{l}\text { Retailer's sale price/consumer } \\
\text { purchase price }\end{array}$ & 5697.42 & 100 \\
\hline
\end{tabular}

Table 3: Marketing cost and marketing margins

\begin{tabular}{|c|c|c|c|c|}
\hline $\begin{array}{l}\text { Sl. } \\
\text { No. }\end{array}$ & Particulars & $\begin{array}{c}\text { Channel } \\
\text { - I }\end{array}$ & $\begin{array}{c}\text { Channel } \\
\text { - II }\end{array}$ & $\begin{array}{c}\text { Channel } \\
\text { - III }\end{array}$ \\
\hline 1 & $\begin{array}{l}\text { Net price received by } \\
\text { farmer (FP) }\end{array}$ & 5045 & 5070 & 5095 \\
\hline 2 & $\begin{array}{c}\text { Total marketing cost } \\
(\mathrm{MC})\end{array}$ & 505.53 & 221.35 & 254.68 \\
\hline 3 & $\begin{array}{l}\text { Total marketing } \\
\text { margin(MM) }\end{array}$ & 784.06 & 236.54 & 347.74 \\
\hline 4 & $\mathrm{MC}+\mathrm{MM}$ & 1289.59 & 457.87 & 602.42 \\
\hline 5 & $\begin{array}{l}\text { Marketing efficiency } \\
\text { (ME) }\end{array}$ & 3.91 & 11.07 & 8.45 \\
\hline
\end{tabular}

Marketing efficiency is the measurement which explains the relationship between marketing variables and the efficiency of the marketing system. Larger the value of marketing efficiency, more efficient will be market and vice-versa. The marketing efficiency of cluster bean is 3.91, 11.07 and 8.45 in channels-I, II and III, respectively (Table$3)$. Therefore, channel-II is more efficient (11.07) than the other two channels i.e. III (8.45) and I (3.91).

\section{CONCLUSION}

It reveals from the study that the marketing cost incurred by the producer, wholesaler, miller and retailer was $0.86,1.28,5.30$ and 0.52 per cent of consumer rupee, respectively in channels I. The same are $0.99,2.41$ and 0.59 percent, respectively in channel II. Similarly, these are 0.96, 1.44, 1.38 and 0.66 per cent, respectively in channel III. It is also evident that channel-II is more efficient than channels-I and III. Based on the results, few points can be suggested for efficient marketing of this crop. These are (1) subsidized transportation facilities should be provided during the harvesting of the crop, (2) there is a need to establish sound market intelligence system so that the farmers can sell their produce in those markets where prices are remunerative, (3) the malpractices in the market should also be checked so that the farmers get fair deal, (4) it is well known that the small farmers do not have the economic strength to retain the produce for remunerative price. Therefore, storage facilities can be strengthened at the village level under Gramin Bhandaran Yojana.

\section{REFERENCES}

Anonymous 2015-16. Directorate of economics and statistics, Pant Krishi Bhawan, Jaipur (Rajasthan) India.

Thakare, S.S., Naphade, S.A. and Vinode, A.K. 2011. Economics of production and marketing of cowpea. Indian Journal of Agricultural Marketing, 25(2): 66-76.

NIAM 2014. An Analysis of Performance of Guar Crop in India, NIAM , Jaipur for United States Department of Agriculture (USDA), New Delhi.

Mudgil, Deepak Barak, Sheweta and Khatkar, B.S. 2014. Guar gum: processing, properties and food applications - A Review. J. Food Sci. Technol., 51(3): 409-418.

NIAM 2013. Guar Industry Outlook 2015 CCS National Institute of Agricultural Marketing (NIAM), Ministry of Agriculture, Government of India. 